\title{
QUALITY FUNCTION DEPLOYMENT, FEASIBILITY ANALYSIS ON DIESEL TANK OF TRUCK VEHICLES
}

\author{
N. JAYASHANKAR ${ }^{1}$, M S. PRABHU SWAMY ${ }^{2} \&$ S A. MOHAN KRISHNA ${ }^{3}$ \\ ${ }^{1,3}$ Department of Mechanical Engineering, VVCE, Mysur \\ ${ }^{2}$ Department of Mechanical Engineering, SJCE, Mysuru
}

\begin{abstract}
The fuel tank is an important component in any of the automobile vehicles, wherein which the flammable liquid called diesel or petrol is stored to run a vehicle engine. Irrespective of the fuel tank designs, like cylindrical tank and rectangular tank, most commonly seen. Even there are some defects in the running tank design may be the corrosion of the tank. Design of a fuel tank includes its material cost, manufacturing cost, transportation cost, and cost of mounting the tank and so on which reflects reliability, strength and performance and so on. Quality Function Deployment (QFD) is also used to in decision making and selection of materials using feasibility analysis.

KEYWORDS: Fuel Tank, Feasibility, QFD, Manufacturing
\end{abstract}

Received: Jun 08, 2020; Accepted: Jun 28, 2020; Published: Aug 11, 2020; Paper Id.: IJMPERDJUN2020735

\section{INTRODUCTION}

Quality Function Deployment (QFD) is considered and along with the salient factors that need in the design considered in designing an effective fuel tank using feasibility analysis. The choice of shape is generally influenced by the need for maximum fuel capacity and the desire for a stylish look. The most common diesel tank designs are cylindrical, rectangular and D-Style tanks. Cylindrical designs are often selected for their visual appeal while the rectangular tank is most often employed to maximize fuel volume for a given space. The QFD helps in selection of best among the considered materials

\section{QFD METHODOLOGY}

By obtaining the components of QFD as shown in Fig 1, relationships are established compared and analyzed. FDapproach provides a great opportunity to work with cross-functional teams, employee involvement and participating management by discussing the meaning and importance of the 'WHATs, HOWs, WHY's combinations. These strategic issues indicate that starting a QFD activity yields multiple benefits title. QFD 


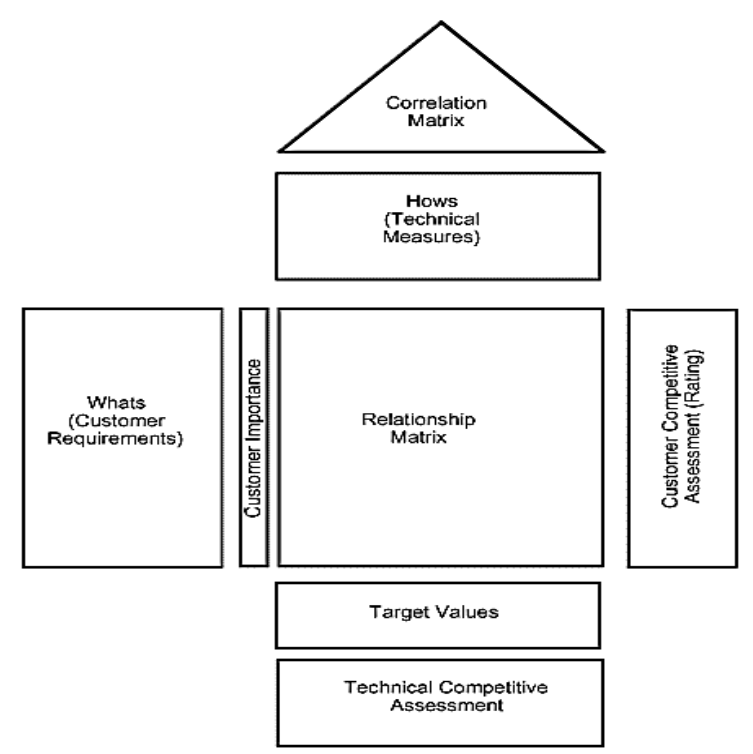

Figure 1: Components of QFD.

\section{OBJECTIVES}

The main objective is to find out better suitable material for diesel tank of truck vehicles upon their application. Using QFD is incorporated in feasibility of fuels tank. The methodology adopted is questionnaire for QFD and design for feasibility analysis. After the collection of information from various mechanics, demographics, experience prime changes are incorporated in the design, the complete 3D model of existing and proposed design was created by using Pro-E software.

The comparative study was made and conclusions of Factors considered are aesthetics, performance, functional, failure reasons, and time frequency of failure

Table 1: Demographic Information

\begin{tabular}{|c|c|l|}
\hline Age $<\mathbf{4 0}$ & Age $>\mathbf{4 0}$ & \\
\hline 16 & 16 & \\
\hline 100 & 100 & Response rate \\
\hline
\end{tabular}

\section{MATERIAL COMPARISON}

The suitable materials for fuel tanks are steel, aluminum and high-density polyethylene (HDPE). Here the comparison of above three materials is shown based on the self-weight of the tank, and also fuel efficiency due to decrease in weight of fuel tank. The material properties are as shown below.

Table 2: Material Properties Comparison

\begin{tabular}{|l|c|c|c|}
\hline \multicolumn{1}{|c|}{ Material Parameter } & STEEL & ALUMINUM & HDPE \\
\hline Density $\left(\mathrm{g} / \mathrm{cm}^{3}\right)$ & 7.89 & 2.70 & 0.95 \\
\hline Poisson's Ratio & 0.3 & 0.33 & 0.46 \\
\hline Yield Strength $(\mathrm{Pa})$ & $210 \times 10^{\mathbf{2}}$ & $\mathbf{5 5 \times 1 0 ^ { 2 }}$ & $\mathbf{2 6 \times 1 0 ^ { 2 }}$ \\
\hline Capacity of the Tank (liters) & 160 & 160 & 160 \\
\hline Self-Weight of the Tank (kg) & 77 & 27.25 & 9.77 \\
\hline
\end{tabular}




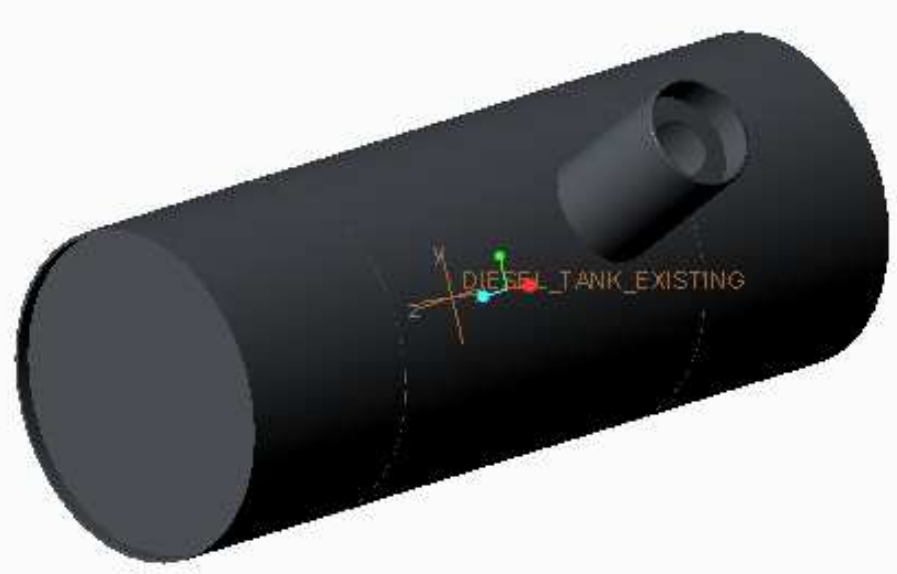

Figure 2

\section{MODELING \& FEASIBILITY ANALYSIS}

Table 3: Comparison of Different Materials

\begin{tabular}{|c|c|c|c|c|}
\hline \multirow{2}{*}{ SL. No. } & \multirow{2}{*}{ PARAMETER } & \multicolumn{3}{|c|}{ MATERIALS } \\
\hline & & STEEL & ALUMINUM & HDPE \\
\hline 1 & Manufacturing & \multicolumn{2}{|c|}{$\begin{array}{l}\text { The raw material used is metal sheets. These tanks are made } \\
\text { by welding the stamped sheet. }\end{array}$} & $\begin{array}{l}\text { These tanks are made } \\
\text { by blow molding or } \\
\text { injection molding. }\end{array}$ \\
\hline 2 & $\begin{array}{l}\text { Corrosion } \\
\text { Resistant }\end{array}$ & $\begin{array}{l}\text { Steel tanks corrodes very } \\
\text { rapidly and it is prevented } \\
\text { by corrosion resistant } \\
\text { paints and zinc coatings }\end{array}$ & $\begin{array}{l}\text { It is also a corrosion resistant } \\
\text { where coatings on the surface } \\
\text { are not required }\end{array}$ & $\begin{array}{l}\text { These tanks are non- } \\
\text { corrosive for long life. }\end{array}$ \\
\hline 3 & Easy Design & \multicolumn{2}{|c|}{$\begin{array}{l}\text { The complex shapes are difficult to manufacture and there } \\
\text { are standard shapes like cylindrical and rectangular tanks. }\end{array}$} & $\begin{array}{l}\text { As compared to the } \\
\text { metal fuel tank } \\
\text { manufacture, HDPE } \\
\text { tanks are easy to } \\
\text { manufacture to their } \\
\text { complex shapes. }\end{array}$ \\
\hline 4 & Recycle & $\begin{array}{l}\text { Steel material can be } \\
\text { recycled easily and used } \\
\text { for further applications. }\end{array}$ & $\begin{array}{l}\text { It is also having an advantage } \\
\text { of recycling the material for } \\
\text { other uses. }\end{array}$ & $\begin{array}{l}\text { Recycle of this plastic } \\
\text { material is hard } \\
\text { because of lack of } \\
\text { infrastructure and } \\
\text { scrap rate is more } \\
\text { compared to steel }\end{array}$ \\
\hline 5 & $\begin{array}{l}\text { Weight } \\
\text { Difference }\end{array}$ & $\begin{array}{l}\text { Weight of the steel tanks is } \\
\text { high because of high } \\
\text { density material } \\
\left(7.89 \mathrm{~g} / \mathrm{cm}^{3}\right) \text {. }\end{array}$ & $\begin{array}{l}\text { Compared to steel tank it is } \\
\text { lower in weight }\left(2.7 \mathrm{~g} / \mathrm{cm}^{3}\right) \text {. }\end{array}$ & $\begin{array}{l}\text { This is a lighter } \\
\text { material and has a least } \\
\text { weight }\left(0.9 \mathrm{~g} / \mathrm{cm}^{3}\right) \text {. }\end{array}$ \\
\hline 6 & Cost & $\begin{array}{l}\text { Steel material is generally } \\
\text { cheaper than the other two } \\
\text { materials. }\end{array}$ & $\begin{array}{l}\text { Cost of aluminum is slightly } \\
\text { higher than compared to steel. }\end{array}$ & $\begin{array}{l}\text { Material cost depends } \\
\text { on low tooling cost for } \\
\text { low volumes and high } \\
\text { tooling cost for high } \\
\text { volumes. }\end{array}$ \\
\hline
\end{tabular}


Table 4: Feasibility Analysis for Different Materials

\begin{tabular}{|c|l|c|c|c|}
\hline \multirow{2}{*}{ SL. No. } & \multirow{2}{*}{ PARAMETER } & \multicolumn{3}{|c|}{ MATERIALS } \\
\cline { 3 - 5 } & & STEEL & ALUMINUM & HDPE \\
\hline 1 & Manufacturing & 5 & 5 & 3 \\
\hline 2 & $\begin{array}{l}\text { Corrosion } \\
\text { Resistant }\end{array}$ & 3 & 3 & 5 \\
\hline 3 & Easy Design & 4 & 3 & 5 \\
\hline 4 & Recycle & 4 & 4 & 5 \\
\hline 5 & $\begin{array}{l}\text { Weight } \\
\text { Difference }\end{array}$ & 3 & 4 & 5 \\
\hline 6 & Cost & 4 & 4 & 5 \\
\hline
\end{tabular}

\section{No Relationship 0 Low Correlation 1}

\section{Medium Correlation 3}

High Correlation 9

Table 5: Important Relations of HOQ

\begin{tabular}{|l|c|c|c|c|}
\hline \multicolumn{1}{|c|}{ MATERIALS } & Priority & Steel & Aluminium & HDPE \\
\hline & & & & \\
\hline Corrosion & & & & \\
\hline Easy Design & & & & 3 \\
\hline Manufacturing & 1 & 1 & 3 & 3 \\
\hline Recycle Weight & 3 & 0 & 3 & 0 \\
\hline Load Applied & & 0 & 0 & 1 \\
\hline Cost & 4 & 0 & 0 & 3 \\
\hline Easy Modification & 5 & 1 & 3 & 6 \\
\hline Life /Reliability & 8 & 0 & 0 & 23 \\
\hline
\end{tabular}

\section{CONCLUSIONS}

In this paper, an attempt has been made to explore the various applications of QFD in different areas or fields in such as design organization.. A quick look of QFD is summarized as a quality tool, universal tool, for majority of the applications with flexibility and quality as main motto.

\section{REFERENCES}

1. Masilamani.R, P.Suresh, P.Tamilazhagan, N.Madhavan, S.Ponnuswamy, "Design and Analysis of High Density Polyethylene Fuel Tank for Heavy Vehicles" IJIRSET, vol-5, Iss-7, April-2016.

2. Kandasamy, A., D B Jabaraj, and M. Chandran. "Investigation of Biodiesel (Jetropha) With Al2o3 in Ci Engine. "International Journal of Mechanical and Production Engineering Research and Development (IJMPERD) 8. 4, Aug 2018, 961-970

3. Gregory A. Keoleian, Sabrina Spatari, Robb T. Beal, Robert D. Stephens, Ronald L. Williams, "Application of life cycle inventory analysis to fuel tank system design”, General Motors, Research Development, USA.

4. Krishnamoorthi, Sangeetha, et al. "Yield Characteristic of Biodiesel Derived From Used Vegetable Oil Methyl Ester (UVOME) Blended With Diesel, in the Presence of Sodium Hydroxide (NAOH) and Potassium Hydroxide (KOH) Catalyst, As Alternative Fuel for Diesel Engines." International Journal of Mechanical and Production Engineering Research and Development (IJMPERD) 8.1 (2018): 9-16. 
5. BaseeraBanushaik, I.Prasanna, "Design and Optimization of HTV Fuel Tank Assembly by Finite Element Analysis", IJMETMR, vol-4, iss-2, Feb-2017.

6. Mohd. Tanveerakthar, “design and analysis of fuel tank” IJRITCC, Vol-3, Iss-2, Feb-2014

7. Shanmugaraj, J., et al. "An Analysis of Diesel Water Emulsion in the Direct Injected Diesel Engine." International Journal of Mechanical and Production Engineering Research and Development 9 (2018): 433-438.

8. Murat kucumen, serdarozkan, cuneytdagdeviren, "fuel tank design and optimization for diesel commercial vehicles according to ECE R34 directives" otekon 2014.

9. 6.John J. Crisiano, Jeffrey K. Liker and Chelsea Cowhide III, "Customer driven product development through quality function deployment in the US and Japan”, Journal of production innovation management, @ Elsevier Science Inc. ,Vol .17, pp 286308,2000

10. Jeyan, Dr JV Murugalal, and AkhilaRupesh."Experimental Investigations on the Performance and Exhaust Emissions of a Diesel Engine Using Jatropha Oil as a Fuel." International Journal of Bio-Technology and Research (IJBTR) 5.4 (2015): $27-$ 36.

11. Govers P.M, "QFD not just a tool but a way of quality management”, International journal of production economics, (C) Elsevier Science Inc, Vol.69, pp 151-159, 2001

12. SwarnaKumar, AnshumanGarnaik “A Case Study in Chair by Applying Quality

13. Function Deployment \&Analytic Hierarchy Process" International Journal of Innovative Research in Science, Engineering and Technology Vol. 5, Issue 1, Januray 2016

\section{AUTHORS PROFILE}

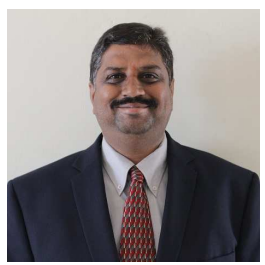

Jaya Shankar $\mathrm{N}$ is working as an Associate Professor in Department of Mechanical Engineering of VVCE. He graduated from the Mysore University and obtained his Masters’ Degree from VTU Belagavi

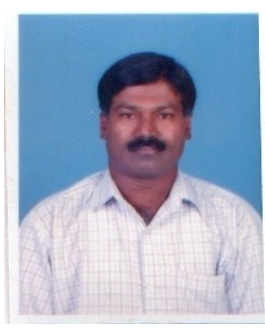

M S Prabhuswamy is the Professor in Department of Mechanical Engineering. He graduated from the Mysore University and obtained his Masters' Degree from Bharathiyar University (PSG Tech Coimbatore) and Doctoral Degree from the IIT Delhi, New Delhi. 


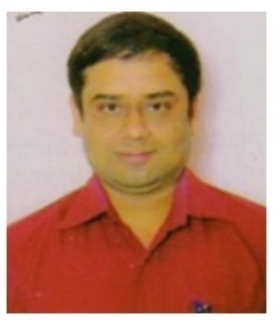

Dr Mohan Krishna SA is working as an Associate Professor in Department of Mechanical Engineering. He graduated from VVCE, VTU and obtained his Masters and doctorate Degree from the same university. 